\title{
Mid-Miocene Lake Level Fluctuations in the Lunpola Basin, Central Tibetan Plateau
}

\author{
Yu Liang ${ }^{1}$, Cheng Quan ${ }^{2}$, Yongxiang $L_{i}^{3}$, Weiguo Liu ${ }^{4}$ and Zhonghui Liu ${ }^{1,4 *}$ \\ ${ }^{1}$ Department of Earth Sciences, The University of Hong Kong, Hong Kong SAR, China, ${ }^{2}$ School of Earth Science and Resources, \\ Chang'an University, Xi'an, China, ${ }^{3}$ State Key Laboratory for Mineral Deposits Research, School of Earth Sciences and \\ Engineering, Nanjing University, Nanjing, China, ${ }^{4}$ State Key Laboratory of Loess and Quaternary Geology, Institute of Earth \\ Environment, Chinese Academy of Sciences, Xi'an, China
}

OPEN ACCESS

Edited by:

Yunfa Miao,

Northwest Institute of ECOEnvironment and Resources (CAS),

China

Reviewed by: Guodong Jia,

Tongji University, China Mingda Wang,

Liaoning Normal University, China

*Correspondence: Zhonghui Liu zhliu@hku.hk

Specialty section:

This article was submitted to Quaternary Science, Geomorphology and Paleoenvironment,

a section of the journal

Frontiers in Earth Science

Received: 03 November 2021 Accepted: 03 December 2021

Published: 21 December 2021

Citation:

Liang Y, Quan C, Li Y, Liu W and Liu Z (2021) Mid-Miocene Lake Level Fluctuations in the Lunpola Basin, Central Tibetan Plateau.

Front. Earth Sci. 9:808266. doi: 10.3389/feart.2021.808266
Knowledge of paleolake evolution is highly important for understanding the past hydroclimate regime on the Tibetan Plateau and associated forcing mechanisms. However, the hydrological history of paleolakes on the central plateau, the core region of the plateau, remains largely inconclusive. Here we present new biomarker records from lacustrine deposits of the Lunpori section in the Lunpola Basin to reconstruct detailed lakelevel fluctuations during the mid-Miocene. A set of $n$-alkane indexes, including the proportion of aquatic macrophytes $\left(\mathrm{P}_{\mathrm{aq}}\right)$, average chain length and carbon preference index as well as the content of $n$-alkanes, vary substantially and consistently throughout the studied interval. Our results altogether show relatively low lake level at $\sim 16.3-15.5 \mathrm{Ma}$ and high lake level before and after the interval, which is in line with the lithological observations in the section. Further comparison with existing regional and global temperature records suggests that lake level fluctuations can be largely linked to global climatic conditions during the mid-Miocene, with lake expansion during relatively warm periods and vice versa. Therefore, we infer that global climatic changes might have controlled the lake-level fluctuations in this region during the mid-Miocene, whereas the tectonic uplift likely played a subordinate role on this timescale.

Keywords: central Tibet, mid-Miocene, paleolake, hydrological evolution, $n$-alkanes

\section{INTRODUCTION}

The Tibetan Plateau, with an area larger than 2.5 million $\mathrm{km}^{2}$ and an average altitude of $\sim 5,000 \mathrm{~m}$ above sea level (a.s.l.) (Spicer et al., 2021), is the most significant landmass in modern Asia (Figure 1A). The plateau growth since the early Cenozoic is widely accepted to shape the environment, climate, and biodiversity in Asia (e.g., Zhisheng et al., 2001; Boos and Kuang, 2010; Molnar et al., 2010; Liu W. et al., 2014; Wang X. et al., 2020; Zhang et al., 2020). During the uplift process, the Tibetan Plateau itself has also undergone dramatic environmental and climatic evolution. For instance, the east-west trending Bangong-Nujiang Suture (BNS), which might be a deep paleovalley separating the Lhasa and Qiangtang blocks (Figure 1A) in the early stage of the plateau growth (Fang et al., 2020) and hosts several sedimentary basins (e.g., Lunpola, Nyima, Bangor) at present, is suggested to have evolved from a wet and warm subtropical ecosystem to a cold and dry condition over the Cenozoic (Deng et al., 2012; Sun et al., 2014; Wu et al., 2017; Mao et al., 2019; Cao et al., 2020; Su et al., 2020). Today, the Tibetan Plateau, known as the "water tower" of Asia, is the origin of most major revers in the Asia (e.g., Yangtze River, Yellow River, and Mekong River), 


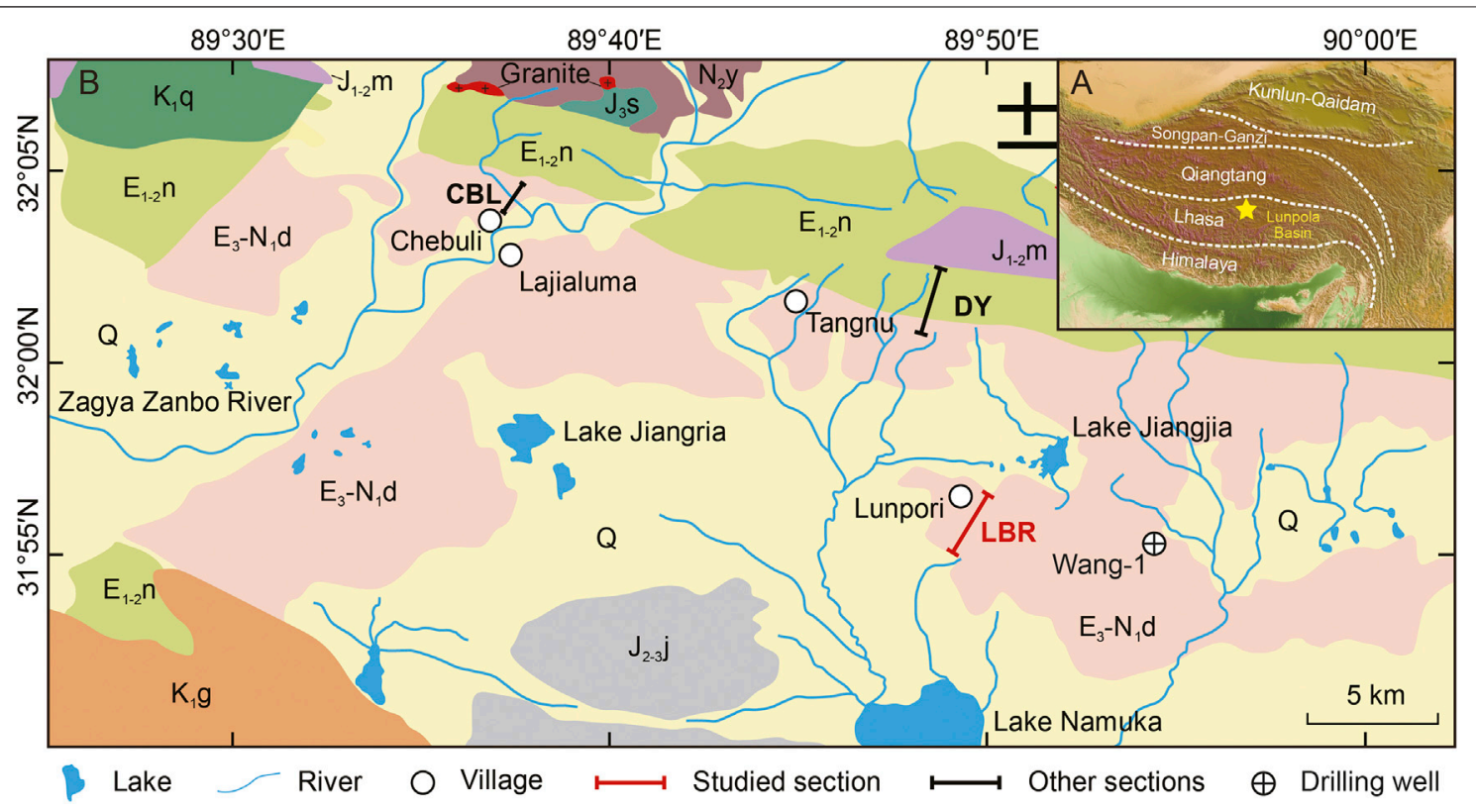

FIGURE 1 | Geological map of the studied region and section. (A) Digital elevation model shows the location of the Lunpola Basin within the Tibetan Plateau terranes. (B) Location of the studied section at the Lunpori village in the Lunpola Basin. Also indicated are previous studied sections, i.e., Chebuli, Dayu, and Wang-1 (Sun et al., 2014; Ma et al., 2017; Fang et al., 2020).

which influences more than half of the global population and thus attracts widespread interests from scientists (Bochiola et al., 2011; Viviroli et al., 2011). Reconstructions of past hydroclimate conditions on the Tibetan Plateau could help us understand the underlying evolution mechanisms, such as global climatic changes and tectonic uplift (e.g., Miao wt al., 2012; Liu W. et al., 2014; Liang et al., 2021). Thick lacustrine deposits have been welldocumented in the basins on the Tibetan Plateau (Sun et al., 2014; Song et al., 2017; Fang et al., 2020; Liang et al., 2021), which directly record the lake evolution and, therefore, provide vital insight into the hydroclimate regime in the region.

Various types of proxy records (e.g., biomarker, ostracod, carbonate and clay mineral) from lacustrine deposits on the Tibetan Plateau show important lake evolution over the Miocene period (Song et al., 2017; Guo et al., 2018; Bao et al., 2019; Liang et al., 2021). For instance, based on multiple biomarker indices, prominent lake expansion is observed in the Qaidam Basin during the midMiocene, followed by a long-term lake shrinkage with substantial fluctuations (Liang et al., 2021). Consistently, this pattern of lake evolution is also revealed by lithologic and geochemical evidence from not only nearby sedimentary basins on the northern plateau (e.g., the Xining Basin, Tianshui Basin, and Longxi Basin) (Peng et al., 2016; Song et al., 2018; Fang et al., 2019) but also the marginal basins on the southern plateau (Lebreton-Anberrée et al., 2016). On the central Tibetan Plateau, the core region of the plateau, earlier studies from the Lunpola Basin (e.g., the Chebuli section, Dayu section, and Wang-1 well, Figure 1B) suggest relatively high altitude, cold-dry condition, and possible lake contraction in the early Miocene (Sun et al., 2014; Jia et al., 2015; Ma et al., 2017; Cao et al., 2020; Fang et al., 2020). These studies have substantially improved our understanding of the evolution of topography and hydroclimate on the central plateau in the early Miocene. However, we know little about the subsequent paleolake status, due to the lack of well-exposed lacustrine sediments and age control, which hampers further understanding of hydrological changes on the entire plateau and associated driving mechanisms. This knowledge gap is filled here by the lake-level reconstructions using the mid-Miocene upper Dingqinghu Formation of the Lunbori section (Figure 1B), retrieved from the Lunpola Basin on the central plateau.

Here we report $n$-alkane records from the upper Dingqinghu Formation in the Lunbori section that can be linked to hydrological changes of the paleolake during the mid-Miocene. A recent detailed magnetostratigraphic study based on zircon dating (Mao et al., 2019) and mammalian fossils (Deng et al., 2012) in the section has constrained this stratigraphic interval to the mid-Miocene period (Tan, 2019). As the Dingqinghu Formation is suggested to deposit in a semi-deep to shallow lacustrine environment in the Lunbori section (Mao et al., 2019), it can effectively document the lake evolution in the Lunpola Basin. Multiple $n$-alkane biomarker indices including the carbon preference index (CPI), average chain length (ACL), and proportion of aquatic plants $\left(\mathrm{P}_{\mathrm{aq}}\right)$, were used to reconstruct lake-level variations. Due to different $n$-alkane distribution patterns in terrestrial and aquatic macrophytes (Liu and Liu, 2016), these indices could directly reflect relative contributions from these organic matter sources, and thus be indicative of lake water depth (Liu Z. et al., 2014; He et al., 2014; Wang Z. et al., 2020; Jiang et al., 2021). In addition, the $n$-alkane content and lithological characteristics, which might be associated with the primary productivity and subaqueous environment respectively (Liu Z. et al., 2014; Liang et al., 2021), were also applied to evaluate lake conditions. By comparing with regional and global climate records and tectonic activities on the Tibetan Plateau, we further inferred the forcing mechanisms which might 


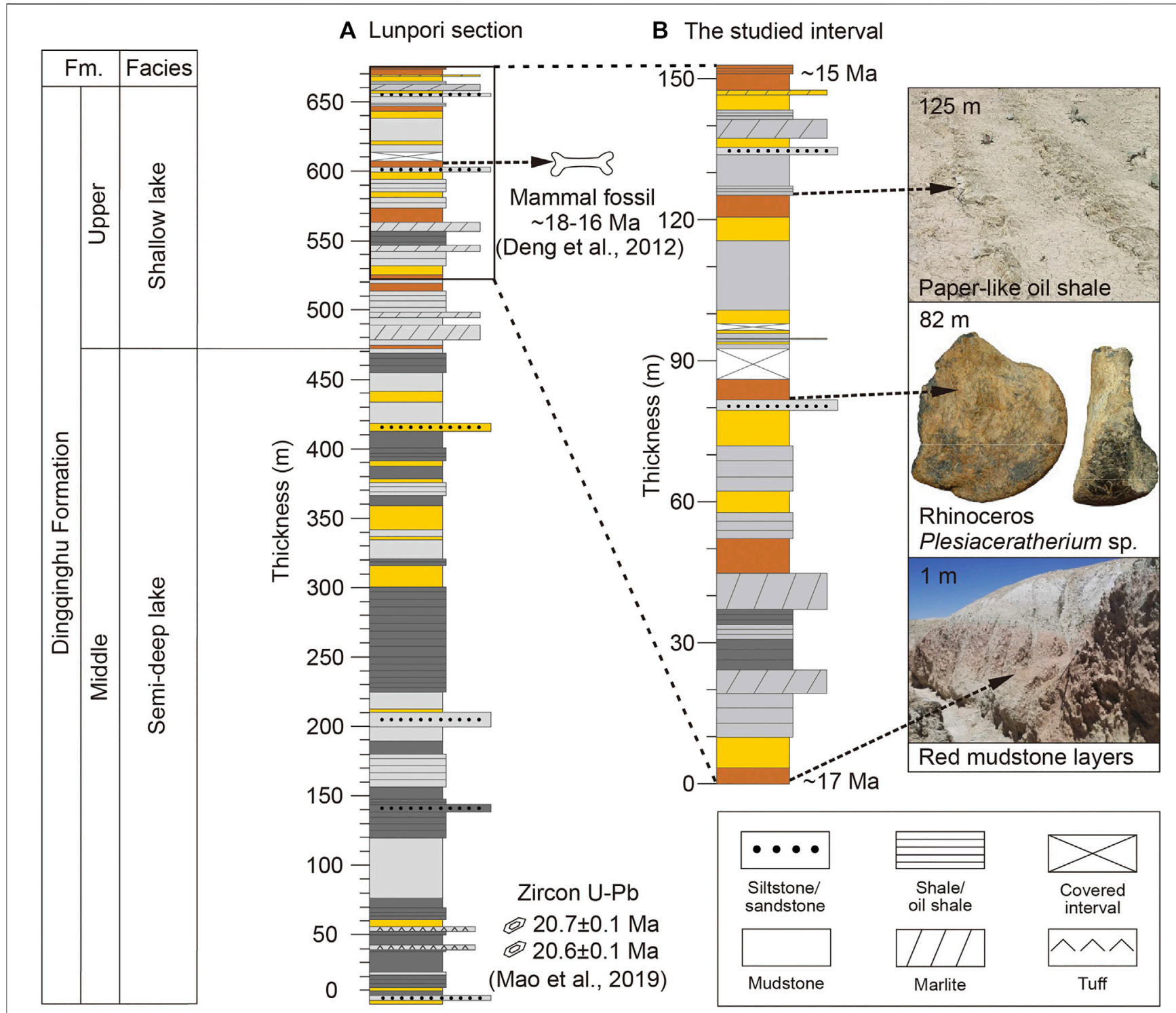

FIGURE 2 | The stratigraphy sequence and lithology of the middle-upper part of the Dingqinghu Formation in the Lunpori section. (A) The entire stratigraphic column shows two age constraints within the Lunpori section, i.e., fossil mammal (Plesiaceratherium sp., Deng et al., 2012) and zircon dating (Mao et al., 2019). (B) Detailed stratigraphic column of our studies interval. Representative photographs of the paper-like oil shale, fossil mammal (Plesiaceratherium sp., Deng et al., 2012), and red mudstone layers respectively. The column colour (i.e., dark grey, light grey, yellow, and red) indicates the colour of the strata.

have induced lake-level fluctuations. Our biomarker records delineate the detailed lake-level history of the Lunpola Basin during the mid-Miocene and provide further constraints on the hydrodynamics on the Tibetan Plateau and its associated forcing mechanisms.

\section{MATERIALS AND METHODS}

\section{Lunpori Section}

The Lunpola Basin, with an altitude of $\sim 4,500 \mathrm{~m}$ a.s.l. and an area of $\sim 3,600 \mathrm{~km}^{2}$, is situated along the southern margin of the BNS belt on the central Tibetan Plateau, framed by the Qiangtang and
Lhasa Terranes (Figure 1A) (Fang et al., 2020). Today, a general basin-wide syncline structure exists in the Lunpola Basin, i.e., the north fold-thrust, the central depression, and the south thrust belt, with the Cenozoic sequence larger than 4,000 m thick including the Dingqinghu and Niubao Formations. The Lunpori section $\left(31^{\circ} 56^{\prime} 18.27^{\prime \prime} \mathrm{N}, 89^{\circ} 48^{\prime} 3.62^{\prime \prime} \mathrm{E}\right)$ is located close to the Lunpori village in the central depression (Figure 1B) where the middle and upper members of the Dingqinghu Formation are well exposed (Figure 2A) (Mao et al., 2019). Our studied interval in this work is the upper part of the Lunpori section (153 m, Figure 2B), which mainly consists of grayish mudstone, silty mudstone, and oil shales intercalated with a few siltstones and marlite layers, indicating relatively stable and shallow lake facies (Figure 2B). 
The depositional age of the Lunpori section is well constrained by zircon U-Pb dating (Mao et al., 2019) and mammal fossil (Deng et al., 2012). First, in the middle Dingqinghu Formation, zircon $\mathrm{U}-\mathrm{Pb}$ dating has yielded concordant ages of $20.6 \pm 0.1$ million years ago (Ma) and $20.7 \pm 0.1 \mathrm{Ma}$ for the tuff layers at the bottom (Mao et al., 2019) (Figure 2A). Second, the mammalian rhino fossil (Plesiaceratherium) reported by Deng et al. (2012) from the upper Dingqinghu Formation has been uncovered worldwide between the Miocene cold events $\mathrm{Mi}-1 \mathrm{~b}$ and $\mathrm{Mi}-2$, implying an age of $\sim 18-16 \mathrm{Ma}$ (Figure 2A). Recently, by using these two types of control points, a detailed magnetostratigraphic study has correlated the entire Lunpori section to the early and midMiocene period (Tan and Liu, 2019). Based on this age assignment (Tan, 2019), the chronology of our studied interval is calculated to be $\sim 16.8-14.7 \mathrm{Ma}$.

\section{Biomarker Analysis}

In our studied interval (153 m), 165 rock samples were collected in total at an average spacing of $\sim 1 \mathrm{~m}$ except for the stratigraphy covered by Quaternary sediments, including mudstone, oil shale, marlite, and silty mudstone. Before extracting organic lipids, we scraped off rock surface and cleaned freshly exposed faces with deionized water. Then, all samples ( $20 \mathrm{~g}$ each $)$ were grounded, freeze-dried, and extracted ultrasonically with dichloromethane (DCM): methanol $(\mathrm{MeOH})$ (9:1 solution; $\mathrm{v} / \mathrm{v}$ ) for three times. Subsequently, the $n$-alkane fraction was separated by silica gel column chromatography using the eluent of $n$-hexane. Finally, we analyzed the $n$-alkanes on an Agilent 7890B Gas Chromatography (GC), equipped with a flame ionization detector (FID), at the University of Hong Kong. Identification of $n$-alkanes was through direct comparisons of retention times with known laboratory standards. All $n$-alkanes were quantified through the external $n-\mathrm{C}_{36}$ standard of a known concentration.

The $n$-alkane indices, namely CPI, modified based on Marzi et al. (1993), $\mathrm{P}_{\mathrm{aq}}$ (Ficken et al., 2000), and ACL (Poynter and Eglinton et al., 1990) were calculated via the following equations:

$$
\begin{aligned}
\mathrm{CPI} & =\left(\mathrm{C}_{19}+\mathrm{C}_{21}+\mathrm{C}_{23}+\ldots+\mathrm{C}_{33}\right) /\left(\mathrm{C}_{20}+\mathrm{C}_{22}+\mathrm{C}_{24}\right) \times(7 / 8) \\
\mathrm{P}_{\mathrm{aq}} & =\left(\mathrm{C}_{23}+\mathrm{C}_{25}\right) /\left(\mathrm{C}_{23}+\mathrm{C}_{25}+\mathrm{C}_{29}+\mathrm{C}_{31}\right) \\
\mathrm{ACL} & =\left(19 \times \mathrm{C}_{19}++21 \times \mathrm{C}_{21}+\ldots+33 \times \mathrm{C}_{33}\right) /\left(\mathrm{C}_{19}+\mathrm{C}_{21}+\ldots+\mathrm{C}_{33}\right)
\end{aligned}
$$

where $C_{i}$ is the concentration of $n$-alkane of $i$ number carbon. Analytical uncertainty of replicated measurements is typically less than $5 \%$ for individual compounds and 0.01 units for ratio-based indices.

\section{RESULTS}

Throughout the records at $\sim 16.8-14.7 \mathrm{Ma}$, the $n$-alkane indices (i.e., $\mathrm{P}_{\mathrm{aq}}, \mathrm{CPI}$, and ACL), as well as the content of $n$-alkanes, vary substantially and consistently (Figure 3; Supplementary Table S1). Generally, the $P_{a q}$ record, ranging from 0.09 to 0.89 , can be divided into three stages (Figure 3A). In detail, higher $\mathrm{P}_{\mathrm{aq}}$ values can be observed during the intervals of $\sim 16.8-16.3$ and 15.5-14.7 Ma (when averaged $\mathrm{P}_{\mathrm{aq}}$ values are 0.44 and 0.38 respectively), while lower $\mathrm{P}_{\mathrm{aq}}$ values exist during the interval of $\sim 16.3-15.5 \mathrm{Ma}$ (with averaged value of 0.29 ). Such a variation pattern could also be recognized in the content of $n$-alkanes (Figure 3D), which changes between $\sim 80$ and $15,000 \mathrm{ng} / \mathrm{g}$, e.g., higher contents during the periods $\sim 16.8-16.3$ and $15.5-14.7 \mathrm{Ma}$ (when averaged values reach 4,100 and $3,300 \mathrm{ng} / \mathrm{g}$ respectively) and lower contents during the period of $\sim 16.3-15.5 \mathrm{Ma}$ (with averaged value of $1800 \mathrm{ng} / \mathrm{g}$ ). The CPI and ACL records, varying from 2.66 to 9.79 and 24.96 to 29.10 respectively, show a distinctly anti-phase relationship with the $\mathrm{P}_{\mathrm{aq}}$ and $n$-alkane content (Figure 3). The episodes of $\sim 16.8-16.3 \mathrm{Ma}$ and $15.5-14.7 \mathrm{Ma}$ are mainly characterized by lower values (with averaged CPI of 4.86 and 4.92 respectively, and averaged ACL of 26.9 and 27.1 respectively). On the contrary, higher CPIs and ACLs occurred during the period of $\sim 16.3-15.5 \mathrm{Ma}$ (when averaged CPI is 5.56 and averaged ACL is 27.8) (Figures 3B,C). Hence, these records are characterized by lower $\mathrm{P}_{\mathrm{aq}}$ and $n$-alkane content values and higher CPI and ACL values at $\sim 16.3-15.5 \mathrm{Ma}$, in addition to the beginning and end of the studied period, whereas the opposite occurred around 16.5 and 15.1 Ma (Figure 3).

\section{DISCUSSION}

\section{Biomarker Interpretation}

In our records, long-chain $n$-alkanes show typical odd-to-even preference (CPI $>3$, Figure $3 \mathrm{C}$ ), indicating that the $n$-alkanes were well preserved in sediments with minor degradation (Liu Z. et al., 2014). All $n$-alkane indices can thus be used to infer the source of organic matters in the paleolake. To date, $n$-alkane distribution patterns in different types of plants have been wellstudied. In general, submerged/floating macrophytes appear to generate significant amount of mid-chain $\mathrm{C}_{21}-\mathrm{C}_{25} n$-alkanes, while terrestrial vascular plants produce more long-chain $\mathrm{C}_{27}$ $\mathrm{C}_{31}$ n-alkanes (Liu Z. et al., 2014; He et al., 2014; Liu and Liu, 2016; Wang Z. et al., 2020). Therefore, the $n$-alkane distribution pattern of dominant mid-chain homologues, as indicated by higher $\mathrm{P}_{\mathrm{aq}}$ and lower ACL values, can be directly linked to more contribution of submerged/floating macrophytes. In contrast, the distribution pattern of dominant long-chain components with lower $\mathrm{P}_{\mathrm{aq}}$ and higher ACL values would imply relative importance of terrestrial input (Jiang et al., 2021). In this sense, we suggest that higher $\mathrm{P}_{\mathrm{aq}}$ and lower ACL values around $16.5 \mathrm{Ma}$ and $\sim 15.1 \mathrm{Ma}$ indicate larger contribution of submerged/floating macrophytes relative to terrestrial input, and vice versa (i.e., $16.3-15.5 \mathrm{Ma}$ ) (Figures 3A,B).

This interpretation is further supported by the CPI record which can also reflect the composition of $n$-alkane pool. Generally, $n$-alkanes produced by the terrestrial vascular tend to have stronger odd-to-even preference, perhaps due to the production of leaf epicuticular waxes (Eglinton and Hamilton, 1967), and thus higher CPI values than aquatic communities (Liu Z. et al., 2014). In our case, intervals of lower CPI values and higher n-alkane contents around $\sim 16.5$ and $\sim 15.1$ Ma (Figures 3C,D), indicative of reduced terrestrial input from adjacent 


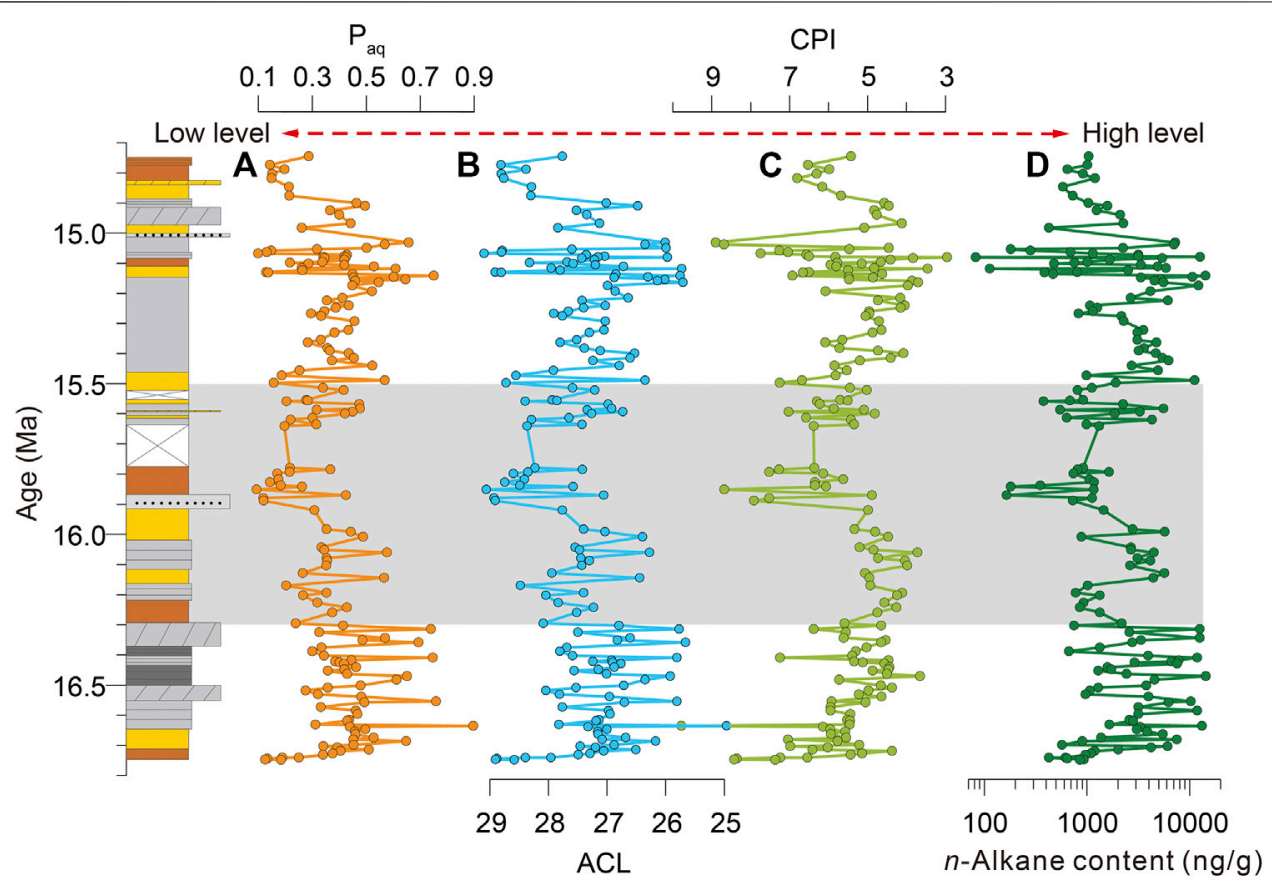

FIGURE 3 | The litho-stratigraphy and records of n-alkane indices, $P_{\text {aq }}(\mathbf{A}), C P I(B)$, and ACL (C), together with the n-alkane content (D), in the Lunpori profile. The greybar marks the interval of relatively low lake level. The legend of the stratigraphic column refers to that in Figure 2.

watersheds, correspond well with intervals of higher $\mathrm{P}_{\mathrm{aq}}$ and lower ACL values (Figures $\mathbf{3 A}, \mathbf{B}$ ). Therefore, all these $n$-alkane indices from the Lunpori section consistently document the sources of organic matters of the paleolake in the Lunpola Basin during the mid-Miocene.

\section{Lake-Level Fluctuations During the Mid-Miocene}

Based on investigations of surface sediments in modern lakes, previous studies suggest that the composition of sedimentary $n$-alkane pool appears to be closely associated with its water depth, which might result from the community structure of aquatic species in the lake ( $\mathrm{Liu} \mathrm{Z}$. et al., 2014; He et al., 2014; Liu and Liu, 2016; Wang Z. et al., 2020; Jiang et al., 2021). Due to the niche differentiation and habitat filtering, an optimum range of water depth is widely accepted to be necessary for the growth of specific aquatic macrophytes (Jones et al., 2002). For instance, emergent plants, which display a similar $n$-alkane distribution pattern with terrestrial plants (i.e., more production of long-chain homologues), are usually the dominant $n$-alkane source along lake littoral zones but gradually replaced by the thrived submerged and floating macrophytes with increasing depth to 1-10 m (Hannon and Gaillard, 1997; Rea et al., 1998; Liu and Liu, 2016; Jiang et al., 2021). Further, terrestrial input from surrounding watersheds would decrease with increasing water depth. Hence, in a relatively shallow lake, such as the paleolake in the Lunpola Basin during the mid-Miocene (Mao et al., 2019), higher $\mathrm{P}_{\mathrm{aq}}$ and lower CPI and ACL values, which reflects more proportion of submerged/floating vs. emergent/terrestrial plants, can be used to infer deeper water depth of the lake. We thus interpret that the lake level in the Lunpola Basin was relatively high around $\sim 16.5$ and $\sim 15.1 \mathrm{Ma}$ and realtively low at 16.3-15.5 Ma, perhaps in addition to the beginning (before $\sim 16.6 \mathrm{Ma}$ ) and end (after $\sim 14.9 \mathrm{Ma}$ ) of the studied interval (Figure 3).

Although lower $\mathrm{P}_{\mathrm{aq}}$ and higher CPI and ACL values could sometimes indicate increased water depth, e.g., in relatively deep lake settings (Liu Z. et al., 2014), the corresponding changes in $n$-alkane content and lithological characteristics, together with the pollen evidence from nearby Chebuli section, do not support such an interpretation in our case. First, during the intervals of higher $\mathrm{P}_{\mathrm{aq}}$ and lower ACL and CPI values (i.e., $\sim 16.8-16.3$ and $\sim 15.5-14.7 \mathrm{Ma}$ ), we also found higher amount of $n$-alkanes (Figure 3) that may be linked to better preservation condition of organic matter and/or enhanced lake primary productivity (minor contribution from terrestrial input as inferred from $n$-alkane indexes), and thus possibly deeper water depth (Liu Z. et al., 2014). Second, relatively low $\mathrm{P}_{\mathrm{aq}}$ and high ACL and CPI valuesare largely observed in the mudstone beds with more silty and light-color sediments, which might have been deposited in relatively shallow and oxidizing subaqueous environment (Figure 3). Third, during the early Miocene when the lake in this basin was realtively deep as compared to the mid-Miocene, based on lithological characteristics, relatively low CPI and ACL values at $\sim 23-22 \mathrm{Ma}$ correspond well with the substantial increase of warm-humid pollen species Keteleeriaepollenites (Sun et al., 2014; Cao et al., 2020), further supporting our interpretation of lower $\mathrm{P}_{\mathrm{aq}}$ and higher $\mathrm{ACL}$ and $\mathrm{CPI}$ values to reflect lower lake level. Therefore, these lines of evidence 


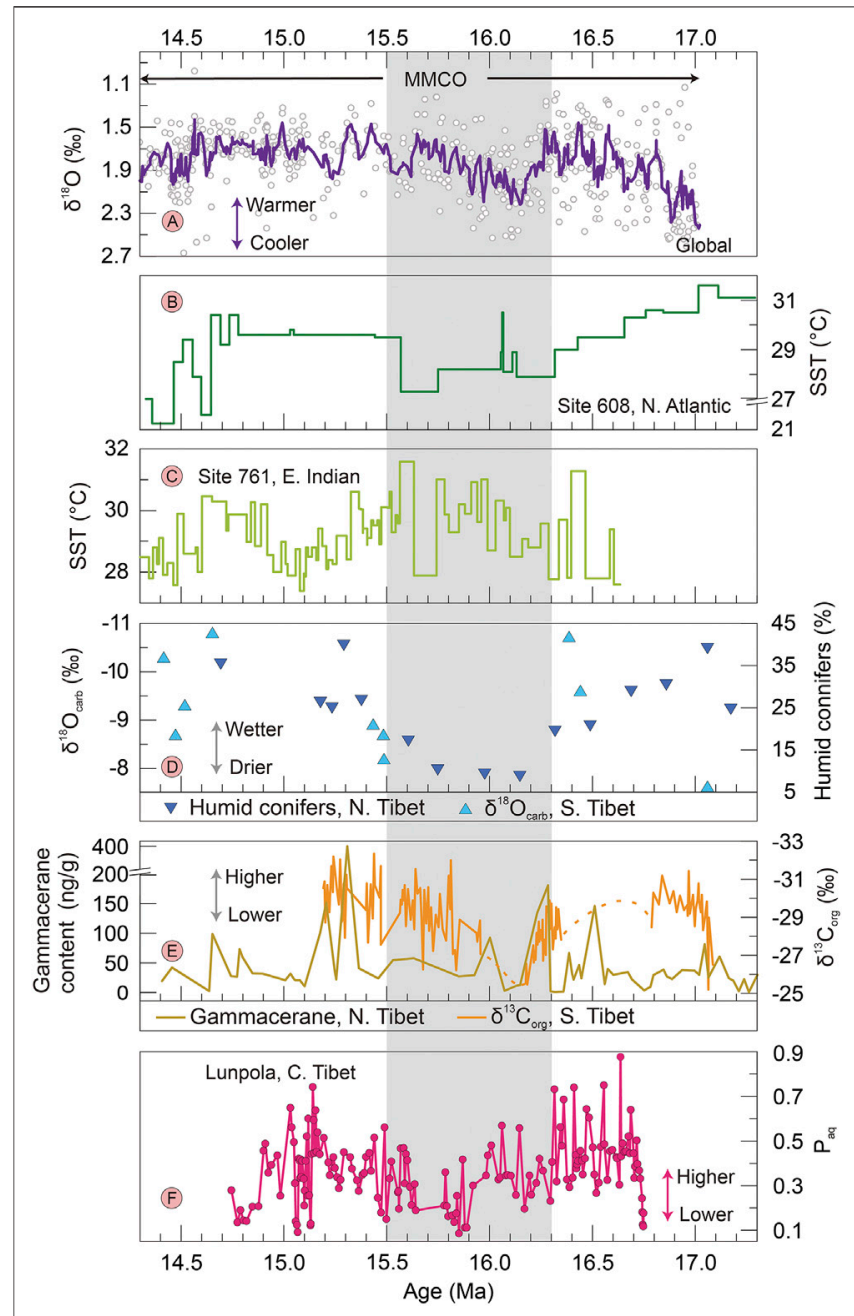

FIGURE 4 | Comparison of representative $n$-alkane index $P_{\text {aq }}$ from the Lunpori section with regional and global records during the middle Miocene. (A) Global benthic foraminiferal $\delta^{18} \mathrm{O}$ (Zachos et al., 2001). (B, C) Sea surface temperature (SST) records from the northern Atlantic Ocean at DSDP site 608 (TEX 86 -based, Super et al., 2018) and the eastern tropical Indian Ocean at ODP site 761 (Mg/Ca-based, Sosdian and Lear, 2020) respectively. (D) Pollen humid conifer percentage from the Qaidam Basin, northern Tibetan Plateau (Miao et al., 2011) and palaeosol carbonate $\delta^{18} \mathrm{O}$ from the Siwalik, southern Tibetan Plateau (Quade et al., 1989). (E) Biomarker gammacerane content from the Qaidam Basin, northern Tibetan Plateau (Liang et al., 2021) and bulk organic $\delta^{13} \mathrm{C}$ from the Wenshan Basin, southern Tibetan Plateau (Lebreton-Anberrée et al., 2016). (F) $P_{\text {aq }}$ values from the Lunpori section (this study). The grey bar indicates the period of relatively low lake level during gobal cool condition. MMCO in (A) denotes the middle Miocene climatic optimum interval.

collectively suggest relatively high lake level around $\sim 16.5 \mathrm{Ma}$ and $\sim 15.1 \mathrm{Ma}$ and low level at $\sim 16.3-15.5 \mathrm{Ma}$ in the Lunpola Basin during the mid-Mioecene.

\section{Associated Forcing Mechanisms}

Today, the northern and southern Tibetan Plateau are mainly controlled by the westerlies and south Asian monsoon respectively, while the central plateau is located in the transition zone receiving mixed moisture from both atmospheric circulations (Yao et al., 2009). As such atmospheric circulation systems might have already been built on the Tibetan Plateau in the early Miocene (Guo et al., 2008; Caves et al., 2015), it can be inferred that the Lunpola Basin on the central Tibetan Plateau was likely influenced by both the westerlies and south Asian monsoon during the studied period, the mid-Miocene. In this study, environmental changes (lake level) inferred from the Lunpori section in the Lunpola Basin are in line with those on the northern and southern Tibetan plateau. For instance, the content of gammacerane and carbon isotope of bulk organic matter $\left(\delta^{13} \mathrm{C}_{\mathrm{org}}\right)$ from the Qaidam (northern Tibetan Plateau) and Wushan Basin (southeastern Tibetan Plateau) respectively (Lebreton-Anberrée et al., 2016; Liang et al., 2021), suggest similar lake level changes during the mid-Miocene (e.g., lake shrinkage at $16.3-15.5 \mathrm{Ma}$ and expand before and after this interval) (Figure 4E). Further, an analogous pattern of detailed fluctuations can also be identified from the moisture records in these regions. Intervals of increased lake level, as indicated by higher $\mathrm{P}_{\mathrm{aq}}$ and lower ACL and CPI values, coincide with intervals of reduced aridity in the northern and southern plateau, as indicated by the higher percentage of humid conifers (Miao et al., 2011) and more negative oxygen isotope $\left(\delta^{18} \mathrm{O}_{\text {carb }}\right)$ of paleosol (Quade et al., 1989) respectively (Figure 4D). Hence, we infer that higher lake level in the Lunpola Basin (e.g., $~ 16.5$ and $15.1 \mathrm{Ma}$ ) might have resulted from enhanced moisture transport from both westerlies and south Asian monsoon, and vice versa (e.g., $16.3-15.5 \mathrm{Ma}$ ).

Moreover, lake-level oscillations display a high degree of consistency with global climatic conditions, with high lake level during the relatively warming period (e.g., $\sim 16.5 \mathrm{Ma}$ and $15.1 \mathrm{Ma}$ ), as suggested by the negative excursion of global benthic $\delta^{18} \mathrm{O}$ (Zachos et al., 2001) (Figure 4A). Similarities of the general patterns are also recognized between our $n$-alkane indices and sea-surface temperature (SST) record from the North Atlantic (Figure 4B) (Super et al., 2018). A SST record from the Indian Ocean (Figure 4C) (Sosdian and Lear, 2020) does not show particular cooling at $\sim 16.3-15.5 \mathrm{Ma}$, perhaps due to chronological uncertainties and relatively small signal of SST changes in tropical oceans. However, the overall pattern of lakelevel changes corresponds well to global benthic $\delta^{18} \mathrm{O}$ changes, indicative of global climatic control on regional temperature and hydrological conditions. It has long been recognized that the concentration of atmospheric water vapor is highly dependent on temperature and also plays an important role in the climate system (Miao et al., 2012; Sun et al., 2020; Liang et al., 2021). During global warmer intervals, strengthened evaporation effect of global oceans would provoke higher moisture level in the atmosphere, exerting significant influence on the continental area. In our case, higher concentration of water vapor would have been carried to the Lunpola Basin by the westerlies and south Asia monsoon when the North Atlantic and Indian Ocean were warmer. Thus, intensified basin moisture level and lake expansion could be associated with global warmer intervals. Such temperature control on regional humidity has also been reported on orbital timescales in westerlies region (Liu W. et al., 2014; Li et al., 2020). 
In addition to global climatic conditions, the tectonic uplift has also been proposed as a potential factor to influence the long-term hydrological evolution on the Tibetan Plateau (Miao et al., 2012; Liu W. et al., 2014; Wang X. et al., 2020; Liang et al., 2021). The growth of nearby mountains could block the delivery of water vapor into the basin and gradually induce lake contraction. In the central Tibetan Plateau, multiple paleoaltimeters including stable isotopes, pollen assemblages, and fossil leaves and mammals indicate that the Lunpola Basin and its surrounding mountain ranges (i.e., Gangdese, Tanggula, and Fenghuoshan Mountains) might have already reached a high elevation close to the modern height prior to the mid-Miocene (Rowley and Currie., 2006; Deng et al., 2012; Sun et al., 2014; Jia et al., 2015; Xu et al., 2018; Fang et al., 2020; Xiong et al., 2020). In this case, the tectonic configuration was inferred to be relatively stable around the Lunpola Basin since the mid-Miocene, and thus tends to exert minor impact on its long-term moisture changes. However, such inference cannot be tested in our study due to the relatively short studied interval. Identifying the role of tectonic uplift in the longterm lake dynamics requires longer records and warrants further research. Our results mainly show the detailed lake-level fluctuations during the mid-Miocene, which correlates well with contemporaneous global climatic changes, rather than the tectonic uplift, i.e., lower lake level under cooler conditions, and vice versa (Figure 4). Overall, we infer that the lake status in the Lunpola Basin, especially the fluctuations, was largely associated with global climatic changes during the mid-Miocene.

\section{CONCLUSION}

Multiple records of $n$-alkane indices and $n$-alkane contents from the Lunpori section consistently document the paleolake evolution in the Lunpola Basin, central Tibetan Plateau during the mid-Miocene. All these records indicate relatively high lake level around $\sim 16.5$ and $\sim 15.1 \mathrm{Ma}$ and low level at $\sim 16.3-15.5 \mathrm{Ma}$ in the Lunpola Basin during the mid-Mioecene. Lake level fluctuations in the basin correspond well to regional and global climatic changes, i.e., lake expansion during relatively warm intervals and shrinkage during relatively cool intervals,

\section{REFERENCES}

Bao, J., Song, C., Yang, Y., Fang, X., Meng, Q., Feng, Y., et al. (2019). Reduced Chemical Weathering Intensity in the Qaidam Basin (NE Tibetan Plateau) during the Late Cenozoic. J. Asian Earth Sci. 170, 155-165. doi:10.1016/ j.jseaes.2018.10.018

Bocchiola, D., Diolaiuti, G., Soncini, A., Mihalcea, C., D’Agata, C., Mayer, C., et al. (2011). Prediction of Future Hydrological Regimes in Poorly Gauged High Altitude Basins: the Case Study of the Upper Indus, Pakistan. Hydrol. Earth Syst. Sci. 15, 2059-2075. doi:10.5194/hess-15-2059-2011

Boos, W. R., and Kuang, Z. (2010). Dominant Control of the South Asian Monsoon by Orographic Insulation versus Plateau Heating. Nature 463, 218-222. doi:10.1038/nature08707

Cao, M., Sun, J., Liu, W., Hou, J., Tian, Q., and Sun, Z. (2020). Paleoclimatic Fluctuations Inferred from Leaf Wax N-Alkane Records in Central Tibet in the Late Oligocene to Early Miocene. Palaeogeogr. Palaeoclimatol. Palaeoecol. 539, 109504. doi:10.1016/j.palaeo.2019.109504 which appears to be primarily linked to global climatic conditions during the mid-Miocene, with the impact of tectonic activities on the hydrological status to be minor on this timescale.

\section{DATA AVAILABILITY STATEMENT}

The original contributions presented in the study are included in the article/Supplementary Material, further inquiries can be directed to the corresponding author.

\section{AUTHOR CONTRIBUTIONS}

Conceptualization: ZL and CQ; investigation: $\mathrm{YuL}, \mathrm{CQ}$, and $\mathrm{YoL}$; formal analysis: YuL, WL, and ZL; funding acquisition: $\mathrm{CQ}, \mathrm{WL}$, and ZL; writing: YuL and ZL led the writing with intellectual contributions from all coauthors.

\section{FUNDING}

This work was supported by National Natural Science Foundation of China (41820104002), the Strategic Priority Research Program of Chinese Academy of Sciences (XDB40000000), and Hong Kong RGC (17305019).

\section{ACKNOWLEDGMENTS}

We sincerely thank guest editors for inviting contribution to this special issue and two referees for providing insightful comments to improve our manuscript.

\section{SUPPLEMENTARY MATERIAL}

The Supplementary Material for this article can be found online at: https:/www.frontiersin.org/articles/10.3389/feart.2021.808266/ full\#supplementary-material

Caves, J. K., Winnick, M. J., Graham, S. A., Sjostrom, D. J., Mulch, A., and Chamberlain, C. P. (2015). Role of the Westerlies in Central Asia Climate over the Cenozoic. Earth Planet. Sci. Lett. 428, 33-43. doi:10.1016/ j.epsl.2015.07.023

Deng, T., Wang, S., Xie, G., Li, Q., Hou, S., and Sun, B. (2012). A Mammalian Fossil from the Dingqing Formation in the Lunpola Basin, Northern Tibet, and its Relevance to Age and Paleo-Altimetry. Chin. Sci. Bull. 57, 261-269. doi:10.1007/s11434-011-4773-8

Eglinton, G., and Hamilton, R. J. (1967). Leaf Epicuticular Waxes. Science 156, 1322-1335. doi:10.1126/science.156.3780.1322

Fang, X., Dupont-Nivet, G., Wang, C., Song, C., Meng, Q., Zhang, W., et al. (2020). Revised Chronology of central Tibet Uplift (Lunpola Basin). Sci. Adv. 6, eaba7298. doi:10.1126/sciadv.aba7298

Fang, X., Fang, Y., Zan, J., Zhang, W., Song, C., Appel, E., et al. (2019). Cenozoic Magnetostratigraphy of the Xining Basin, NE Tibetan Plateau, and its Constraints on Paleontological, Sedimentological and Tectonomorphological Evolution. Earth-Science Rev. 190, 460-485. doi:10.1016/j.earscirev.2019.01.021 
Ficken, K. J., Li, B., Swain, D. L., and Eglinton, G. (2000). An N-Alkane Proxy for the Sedimentary Input of Submerged/floating Freshwater Aquatic Macrophytes. Org. Geochem. 31, 745-749. doi:10.1016/S0146-6380(00) 00081-4

Guo, P., Liu, C., Huang, L., Yu, M., Wang, P., and Zhang, G. (2018). Palaeohydrological Evolution of the Late Cenozoic saline lake in the Qaidam Basin, NE Tibetan Plateau: Tectonic vs. Climatic Control. Glob. Planet. Change 165, 44-61. doi:10.1016/j.gloplacha.2018.03.012

Guo, Z. T., Sun, B., Zhang, Z. S., Peng, S. Z., Xiao, G. Q., Ge, J. Y., et al. (2008). A Major Reorganization of Asian Climate by the Early Miocene. Clim. Past 4, 153-174. doi:10.5194/cp-4-153-2008

Hannon, G. E., and Gaillard, M.-J. (1997). The Plant-Macrofossil Record of Past lake-level Changes. J. Paleolimnol. 18, 15-28. doi:10.1023/A:1007958511729

He, Y., Zheng, Y., Pan, A., Zhao, C., Sun, Y., Song, M., et al. (2014). Biomarkerbased Reconstructions of Holocene lake-level Changes at Lake Gahai on the Northeastern Tibetan Plateau. The Holocene 24, 405-412. doi:10.1177/ 0959683613519689

Jia, G., Bai, Y., Ma, Y., Sun, J., and Peng, P. a. (2015). Paleoelevation of Tibetan Lunpola basin in the Oligocene-Miocene Transition Estimated from Leaf Wax Lipid Dual Isotopes. Glob. Planet. Change 126, 14-22. doi:10.1016/ j.gloplacha.2014.12.007

Jiang, J., Meng, B., Liu, H., Wang, H., Kolpakova, M., Krivonogov, S., et al. (2021). Water Depth Control on N-Alkane Distribution and Organic Carbon Isotope in Mid-latitude Asian Lakes. Chem. Geology. 565, 120070. doi:10.1016/ j.chemgeo.2021.120070

Jones, J. I., Young, J. O., Eaton, J. W., and Moss, B. (2002). The Influence of Nutrient Loading, Dissolved Inorganic Carbon and Higher Trophic Levels on the Interaction between Submerged Plants and Periphyton. J. Ecol. 90, 12-24. doi:10.1046/j.0022-0477.2001.00620.x

Lebreton-Anberrée, J., Li, S., Li, S.-F., Spicer, R. A., Zhang, S.-T., Su, T., et al. (2016). Lake Geochemistry Reveals Marked Environmental Change in Southwest China during the Mid Miocene Climatic Optimum. Sci. Bull. 61, 897-910. doi:10.1007/s11434-016-1095-x

Li, G., Yang, H., Stevens, T., Zhang, X., Zhang, H., Wei, H., et al. (2020). Differential Ice Volume and Orbital Modulation of Quaternary Moisture Patterns between Central and East Asia. Earth Planet. Sci. Lett. 530, 115901. doi:10.1016/ j.epsl.2019.115901

Liang, Y., Zhang, B., Zhang, Y., Zhang, Y., Wang, J., and Liu, Z. (2021). Evolution of the Miocene Megalake in the Western Qaidam Basin, Northwestern China. Palaeogeogr. Palaeoclimatol. Palaeoecol. 571, 110384. doi:10.1016/ j.palaeo.2021.110384

Liu, H., and Liu, W. (2016). $n$-Alkane Distributions and Concentrations in Algae, Submerged Plants and Terrestrial Plants from the Qinghai-Tibetan Plateau. Org. Geochem. 99, 10-22. doi:10.1016/j.orggeochem.2016.06.003

Liu, W., Liu, Z., An, Z., Sun, J., Chang, H., Wang, N., et al. (2014a). Late Miocene Episodic Lakes in the Arid Tarim Basin, Western China. Proc. Natl. Acad. Sci. USA 111, 16292-16296. doi:10.1073/pnas.1410890111

Liu, Z., Zhang, K., Sun, Y., Liu, W., Liu, Y. C., and Quan, C. (2014b). Cenozoic Environmental Changes in the Northern Qaidam Basin Inferred Fromn-Alkane Records. Acta Geologica Sinica - English Edition 88, 1547-1555. doi:10.1111/ $1755-6724.12317$

Ma, P., Wang, C., Meng, J., Ma, C., Zhao, X., Li, Y., et al. (2017). Late OligoceneEarly Miocene Evolution of the Lunpola Basin, central Tibetan Plateau, Evidences from Successive Lacustrine Records. Gondwana Res. 48, 224-236. doi:10.1016/j.gr.2017.04.023

Mao, Z., Meng, Q., Fang, X., Zhang, T., Wu, F., Yang, Y., et al. (2019). Recognition of Tuffs in the Middle-Upper Dingqinghu Fm., Lunpola Basin, central Tibetan Plateau: Constraints on Stratigraphic Age and Implications for Paleoclimate. Palaeogeogr. Palaeoclimatol. Palaeoecol. 525, 44-56. doi:10.1016/ j.palaeo.2019.03.040

Marzi, R., Torkelson, B. E., and Olson, R. K. (1993). A Revised Carbon Preference index. Org. Geochem. 20, 1303-1306. doi:10.1016/0146-6380(93)90016-5

Miao, Y., Fang, X., Herrmann, M., Wu, F., Zhang, Y., and Liu, D. (2011). Miocene Pollen Record of KC-1 Core in the Qaidam Basin, NE Tibetan Plateau and Implications for Evolution of the East Asian Monsoon. Palaeogeogr. Palaeoclimatol. Palaeoecol. 299, 30-38. doi:10.1016/j.palaeo.2010.10.026

Miao, Y., Herrmann, M., Wu, F., Yan, X., and Yang, S. (2012). What Controlled Mid-late Miocene Long-Term Aridification in Central Asia? - Global Cooling or Tibetan Plateau Uplift: A Review. Earth-Science Rev. 112, 155-172. doi:10.1016/j.earscirev.2012.02.003

Molnar, P., Boos, W. R., and Battisti, D. S. (2010). Orographic Controls on Climate and Paleoclimate of Asia: Thermal and Mechanical Roles for the Tibetan Plateau. Annu. Rev. Earth Planet. Sci. 38, 77-102. doi:10.1146/annurev-earth040809-152456

Peng, T., Li, J., Song, C., Guo, B., Liu, J., Zhao, Z., et al. (2016). An Integrated Biomarker Perspective on Neogene-Quaternary Climatic Evolution in NE Tibetan Plateau: Implications for the Asian Aridification. Quat. Int. 399, 174-182. doi:10.1016/j.quaint.2015.04.020

Poynter, J., and Eglinton, G. (1990). Molecular Composition of Three Sediments from Hole 717C: The Bengal Fan. Proc. Ocean Drilling Program-Scientific Results 116, 155-161. doi:10.2973/odp.proc.sr.116.151.1990

Quade, J., Cerling, T. E., and Bowman, J. R. (1989). Development of Asian Monsoon Revealed by Marked Ecological Shift during the Latest Miocene in Northern Pakistan. Nature 342, 163-166. doi:10.1038/ $342163 \mathrm{a} 0$

Rea, T. E., Karapatakis, D. J., Guy, K. K., Pinder III, J. E., III, and Mackey Jr, H. E., Jr (1998). The Relative Effects of Water Depth, Fetch and Other Physical Factors on the Development of Macrophytes in a Small southeastern US Pond. Aquat. Bot. 61, 289-299. doi:10.1016/S0304-3770(98)00069-2

Rowley, D. B., and Currie, B. S. (2006). Palaeo-altimetry of the Late Eocene to Miocene Lunpola basin, central Tibet. Nature 439, 677-681. doi:10.1038/ nature04506

Song, B., Ji, J., Wang, C., Xu, Y., and Zhang, K. (2017). Intensified Aridity in the Qaidam Basin during the Middle Miocene: Constraints from Ostracod, Stable Isotope, and Weathering Records. Can. J. Earth Sci. 54, 242-256. doi:10.1139/ cjes-2016-0052

Song, Y., Wang, Q., An, Z., Qiang, X., Dong, J., Chang, H., et al. (2018). MidMiocene Climatic Optimum: Clay mineral Evidence from the Red clay Succession, Longzhong Basin, Northern China. Palaeogeogr. Palaeoclimatol. Palaeoecol. 512, 46-55. doi:10.1016/j.palaeo.2017.10.001

Sosdian, S. M., and Lear, C. H. (2020). Initiation of the Western Pacific Warm Pool at the Middle Miocene Climate Transition? Paleoceanography and Paleoclimatology 35, 1-20. doi:10.1029/2020PA003920

Spicer, R. A., Su, T., Valdes, P. J., Farnsworth, A., Wu, F.-X., Shi, G., et al. (2021). Why 'the Uplift of the Tibetan Plateau' Is a Myth. Natl. Sci. Rev. 8, nwaa091. doi:10.1093/nsr/nwaa091

Su, T., Spicer, R. A., Wu, F.-X., Farnsworth, A., Huang, J., Del Rio, C., et al. (2020). A Middle Eocene lowland Humid Subtropical "Shangri-La" Ecosystem in central Tibet. Proc. Natl. Acad. Sci. USA 117, 32989-32995. doi:10.1073/ pnas. 2012647117

Sun, J., Xu, Q., Liu, W., Zhang, Z., Xue, L., and Zhao, P. (2014). Palynological Evidence for the Latest Oligocene-early Miocene Paleoelevation Estimate in the Lunpola Basin, central Tibet. Palaeogeogr. Palaeoclimatol. Palaeoecol. 399, 21-30. doi:10.1016/j.palaeo.2014.02.004

Sun, Y., Liu, J., Liang, Y., Ji, J., Liu, W., Aitchison, J. C., et al. (2020). Cenozoic Moisture Fluctuations on the Northeastern Tibetan Plateau and Association with Global Climatic Conditions. J. Asian Earth Sci. 200, 104490. doi:10.1016/ j.jseaes.2020.104490

Super, J. R., Thomas, E., Pagani, M., Huber, M., O'Brien, C., and Hull, P. M. (2018). North Atlantic Temperature and pCO2 Coupling in the Early-Middle Miocene. Geology 46, 519-522. doi:10.1130/G40228.1

Tan, M. (2019). Data from: Paleomagnetic Data from the Lunpola Basin. Natl. Tibet. Plateau Data Cent. doi:10.11888/Geo.tpdc.270282

Viviroli, D., Archer, D. R., Buytaert, W., Fowler, H. J., Greenwood, G. B., Hamlet, A. F., et al. (2011). Climate Change and Mountain Water Resources: Overview and Recommendations for Research, Management and Policy. Hydrol. Earth Syst. Sci. 15, 471-504. doi:10.5194/hess-15-471-2011

Wang, X., Carrapa, B., Sun, Y., Dettman, D. L., Chapman, J. B., Caves Rugenstein, J. K., et al. (2020a). The Role of the Westerlies and Orography in Asian Hydroclimate since the Late Oligocene. Geology 48, 728-732. doi:10.1130/ G47400.1

Wang, Z., Zhang, F., Li, X., Cao, Y., Hu, J., Wang, H., et al. (2020b). Changes in the Depth of Lake Qinghai since the Last Deglaciation and Asynchrony between lake Depth and Precipitation over the Northeastern Tibetan Plateau. Glob. Planet. Change 188, 103156. doi:10.1016/ j.gloplacha.2020.103156 
Wu, F., Miao, D., Chang, M.-m., Shi, G., and Wang, N. (2017). Fossil Climbing Perch and Associated Plant Megafossils Indicate a Warm and Wet central Tibet during the Late Oligocene. Sci. Rep. 7, 878. doi:10.1038/s41598-01700928-9

Xiong, Z., Ding, L., Spicer, R. A., Farnsworth, A., Wang, X., Valdes, P. J., et al. (2020). The Early Eocene Rise of the Gonjo Basin, SE Tibet: From Low Desert to High forest. Earth Planet. Sci. Lett. 543, 116312. doi:10.1016/ j.epsl.2020.116312

Xu, Q., Ding, L., Spicer, R. A., Liu, X., Li, S., and Wang, H. (2018). Stable Isotopes Reveal Southward Growth of the Himalayan-Tibetan Plateau since the Paleocene. Gondwana Res. 54, 50-61. doi:10.1016/j.gr.2017.10.005

Yao, T., Zhou, H., and Yang, X. (2009). Indian Monsoon Influences Altitude Effect of $\delta 18 \mathrm{O}$ in Precipitation/river Water on the Tibetan Plateau. Sci. Bull. 54, 2724-2731. doi:10.1007/s11434-009-0497-4

Zachos, J., Pagani, M., Sloan, L., Thomas, E., and Billups, K. (2001). Trends, Rhythms, and Aberrations in Global Climate 65 Ma to Present. Science 292, 686-693. doi:10.1126/science.1059412

Zhang, Z., Sun, J., Tian, S., Lü, L., Su, B., Cao, M., et al. (2020). Environmental Magnetic Evidence for Enhanced Aridification in the Tarim Basin since $~ 5.3$ Ma, NW China. J. Asian Earth Sci. 189, 104181. doi:10.1016/ j.jseaes.2019.104181
Zhisheng, A., Kutzbach, J. E., Prell, W. L., and Porter, S. C. (2001). Evolution of Asian Monsoons and Phased Uplift of the Himalaya-Tibetan Plateau since Late Miocene Times. Nature 411, 62-66. doi:10.1038/35075035

Conflict of Interest: The authors declare that the research was conducted in the absence of any commercial or financial relationships that could be construed as a potential conflict of interest.

Publisher's Note: All claims expressed in this article are solely those of the authors and do not necessarily represent those of their affiliated organizations, or those of the publisher, the editors and the reviewers. Any product that may be evaluated in this article, or claim that may be made by its manufacturer, is not guaranteed or endorsed by the publisher.

Copyright (C) 2021 Liang, Quan, Li, Liu and Liu. This is an open-access article distributed under the terms of the Creative Commons Attribution License (CC BY). The use, distribution or reproduction in other forums is permitted, provided the original author(s) and the copyright owner(s) are credited and that the original publication in this journal is cited, in accordance with accepted academic practice. No use, distribution or reproduction is permitted which does not comply with these terms. 